\title{
LASER-MICRO/NANOFABRICATED 3D POLYMERS FOR TISSUE ENGINEERING APPLICATIONS
}

\author{
P. Danilevičius ${ }^{1}$, A. Žukauskas ${ }^{1}$, G. Bičkauskaité ${ }^{1}$, V. Purlys ${ }^{1}$, M. Rutkauskas ${ }^{1}$, \\ T. Gertus ${ }^{1}$, D. Paipulas ${ }^{1}$, J. Matukaite ${ }^{2}$, D. Baltriukiené $\dot{3}^{3}$, M. Malinauskas ${ }^{1}$ \\ ${ }^{1}$ Department of Quantum Electronics, Physics Faculty, Vilnius University, \\ 9-3 Sauletekio Av., Vilnius, LT-10223, LITHUANIA \\ ${ }^{2}$ Trakai Hospital, Faculty of Medicine, Vilnius University, \\ 21 M.K.Čiurlionio Str., Vilnius, LT-03101, LITHUANIA \\ ${ }^{3}$ Vivarium, Institute of Biochemistry, Vilnius University, \\ 12 Mokslininkų Str., Vilnius, LT-08662, LITHUANIA \\ mangirdas.malinauskas@ff.vu.lt
}

\begin{abstract}
A multi-photon polymerization system has been designed based on a pulsed irradiation light source (diode-pumped solid state femtosecond laser $\mathrm{Yb}: \mathrm{KGW}, 300 \mathrm{fs}$, $1030 \mathrm{~nm}, 1-200 \mathrm{kHz}$ ) in combination with large working area and high precision linear motor driven stages $\left(100 \times 100 \times 50 \mathrm{~mm}^{3}\right)$. The system is intended for high resolution and throughput 3D micro- and nanofabrication and enables manufacturing the polymeric templates up to $1 \mathrm{~cm}^{2}$ areas with sub-micrometer resolution. These can be used for producing $3 \mathrm{D}$ artificial polymeric scaffolds to be applied for growing cells, specifically, in the tissue engineering. The bio-compatibility of different acrylate, hybrid organic-inorganic and biodegradable polymeric materials is evaluated experimentally in vitro. Variously sized and shaped polymeric scaffolds of biocompatible photopolymers with intricate 3D geometry were successfully fabricated. Proliferation tests for adult rabbit myogenic stem cells have shown the applicability of artificial scaffolds in biomedicine practice.

Keywords: femtosecond laser, micro- and nanofabrication, photopolymerization, expansion experiments, $3 D$ nanolithography, artificial scaffolds, stem cells, regenerative medicine.
\end{abstract}

\section{INTRODUCTION}

Laser micro- and nanofabrication technique of polymers via multi-photon polymerization (MPP) has grown significantly during the past decade [1]. The tightly focused femtosecond pulse induced photomodification reaction confined within a femtolitre volume corresponding to the vicinity of focus allows easy formation of true 3D micro- and nanostructures directly from pre-programmed computer-aided design (CAD) models [2]. This structuring possibility sets off the MPP technique among other nanostructuring alternatives, such as UV [3], electron beam [4], nanoimprint lithographies [5], self-organization of nanoparticles [6], etc., and provides direct real 3D photostructuring. Comparing with other microstructuring technologies, e.g. soft-lithography [7], $\mu$-stereolithography [8], and ink-jet printing [9], it ensures higher spatial structuring resolution [10]. MPP-based di- 
versified applications have already arisen - micromechanics [11], microfluidics [12], photonics [13], microoptics [14] as well as biological applications [15].

Due to diseases or traumas the demand on tissues which could be transplanted into the patient is high [16]. At this point, studies are focused on producing artificial scaffolds which could act as skeletons for controllably growing stem cells forming artificial tissues [17]. Precise MPP technology satisfies the requirements of 3D structuring and bio-compatibility of the materials used [18]. Furthermore, proliferation and differentiation of stem cells can be controlled by changing chemical and mechanical properties of the original materials [19]. New approaches the use of embryonic stem cells as a cell source and the novel design of 3D scaffolds - hold promise for the patients who need tissue repair and organ replacement [20].

Nowadays, complex-shaped polymeric matrices are designed for growing the primary stem cells with a controlled porosity, since every type of tissue has its individual optimal pore sizes for cells to grow [20]. In work [21] it was shown that the pore size of $5 \mu \mathrm{m}$ is sufficient for neovascularization. In turn, it has been reported [22] that in chondrocyte culture a greater number of chondrocytes appear in spherical chondrocytic morphology and are more closely packed in a scaffold with $20 \mu \mathrm{m}$ pore size against the one of $80 \mu \mathrm{m}$. At a bigger pore size, chondrocytes prefer to spread over the pore walls, since elongated morphology and cell-cell interaction is limited. For fibroblast ingrowth, the optimal pore size was found to be $20 \mu \mathrm{m}$ [23]. However, a large pore size (up to $500 \mu \mathrm{m}$ ) was also successfully used for fibrovascular tissue ingrowth [24]. For adult mammalian skin, pore size range of 20-125 $\mu \mathrm{m}$ was found to be optimal [25]. The range of 135-633 $\mu \mathrm{m}$ was applied to engineer the adipose tissue [26]. The effect of pore size on the bone ingrowth provided by various scaffolds in the bone engineering covers 10-800 $\mu \mathrm{m}$. Pore sizes of 200-400 $\mu \mathrm{m}$ were suggested to be the optimum, while those of 80 $100 \mu \mathrm{m}$ considered as the minimum for bone ingrowth due to osteoconduction [27]. According to these authors the optimal pore size of the scaffolds depends on the mechanism of tissue regeneration; however, in the MPP technique the porosity of a constructed scaffold can be precisely controlled.

The biodegradation as well as biostability of the scaffold is essential to match the rate of neotissue formation [28]. The MPP can be used both with biodegradable and biostable materials, depending on the target application. The MPPproduced scaffolds have the required mechanical integrity and maintain the predesigned tissue structure; besides, the created scaffolds are proved to be non-cytotoxic and positively interacting with cells. What is more, the MPP-engineered scaffolds do not interfere with cell migration, growth, adhesion, and differentiation [29].

Currently, novel technologies emerge that seem to meet the requirements for 3D scaffold fabrication [15]. In particular, the direct laser writing is a very promising approach as the optical maskless lithography, which offers flexibility, ease of use, and cost effectiveness in R\&D processing [30,31]. This technique provides rapid patterning at sub-micron resolutions, compromising between performance and costs when working with feature sizes of about $200 \mathrm{~nm}$ or higher comparing with $\mu$-stereolithography or electron beam writing [32-35]. As compared with alternative technologies, it offers unique 3D sculpting ability without any geometry features $[17,36]$. The MPP is also attractive for easy scalability and flexibility at 
structuring arbitrary textures in various biocompatible polymers [37, 38]. However, for application in the tissue engineering much effort still has to be applied both to improving the scaffold fabrication technology and to understanding the cell behaviour at a micro-scale in three dimensions [39].

In this paper, we present the results of our progress in applying the MPP system designed for fabrication of 3D scaffolds and in testing their biocompatibility in vitro using rabbit stem cells.

\section{EXPERIMENTAL}

\subsection{Photosensitive materials}

In the experiments, we used three different negative photopolymers: custommade acrylate-based material AKRE [31, 38], hybrid organic-inorganic $\mathrm{Zr}$ containing sol-gel material (ORganicaly MOdified SILica SZ2080, FORTH) [40, 41] and biodegradable PEG-DA-258 (PolyEthylenGlycol Di-Acrylate of M.w. $=258$, Sigma-Aldrich $\mathrm{GmbH})[42,43]$. The pre-polymers were photosensitized adding 1-2 wt.\% of thioxanthen-9-one, 2-benzyl-2-dimethylamino-1-(4-morpholinophenyl)-butanone-1 photoinitiators or 4,4'-bis(dietilamino) benzophenone (Sigma-Aldrich $\mathrm{GmbH}$ ). The chemical formulas of the used materials and applied developers are tabulated below.

Table 1

Photosensitive pre-polymer materials

\begin{tabular}{|c|c|c|}
\hline Material & Chemical formula & Developer \\
\hline AKRE & $\mathrm{C}_{18} \mathrm{H}_{21} \mathrm{~N}_{3} \mathrm{O}_{9}$ & Ethyl alcohol \\
\hline SZ2080 & $\mathrm{C}_{4} \mathrm{H}_{12} \mathrm{SiZrO}_{2}$ & Methyl isobutyl ketone \\
\hline PEG-DA-258 & $\mathrm{C}_{8} \mathrm{H}_{10} \mathrm{O}_{4}$ & Water \\
\hline
\end{tabular}

Samples for fabrication were prepared by drop-casting the photopolymer on a glass substrate (microscope cover slides). After laser processing the samples were treated with the appropriate organic solvent in order to wash out the unexposed material. Light-exposed photopolymer undergoes polymerization and becomes insoluble in the developer, with the polymerized features sustained during the development process. In this way, free-standing structures on a glass substrate were obtained. To investigate the micro-structured scaffolds, scanning electron microscopy (SEM) was applied.

\subsection{Multi-photon polymerization system using femtosecond laser}

Earlier, we constructed and tested a MPP fabrication setup for 3D micro- and nanostructuring of photopolymers over a large area [31,38] (schematically shown in Fig. 1). As the irradiation source, a diode-pumped solid state amplified $\mathrm{Yb}: \mathrm{KGW}$ fs laser system (Pharos, Light Conversion. Co. Ltd.) was used. The laser parameters are: tunable repetition rate $1-200 \mathrm{kHz}$, average power $-6 \mathrm{~W}$, pulse duration - $300 \mathrm{fs}$, and central wavelength - $1030 \mathrm{~nm}$. The expanded fs laser beam was guided through the objective, focusing laser beam into the volume of photopolymer. The sample was mounted on the XYZ wide range positioning stages. The positioning system consists of stages driven by linear motor (Aerotech, Inc.): XY - 
ALS130-100, Z - ALS130-50. These stages ensure an overall travelling range of $100 \mathrm{~mm}$ in the $\mathrm{X}$ - and Y-directions and $50 \mathrm{~mm}$ in the Z-direction, and maintain the translation speed up to $300 \mathrm{~mm} / \mathrm{s}$. Upon irradiation, the pre-polymer undergoes transition from liquid to solid (or from gel to solid), which results in a change in the refractive index. This makes it possible to use the wide-field transmission microscopy for monitoring the fabrication process in real time. The microscope was built by assembling its main components: a source of red light provided by LED, a CMOS (mvBlueFOX-M102G, Matrix Vision GmbH) camera, and a video screen. The ability to image photostructuring while performing MPP is an important feature for the fabrication process to be successful. It is of utmost importance for the microstructures to adhere to the substrate to survive the step of washing the unsolidified resin on the same substrate. Overall equipment control is automated via the custom-made computer software 3DPoli (specially designed for the MPP applications). Due to the 3D-moving of the sample inside resin the position of laser focus is variable, so it is possible to write complex 3D structures. The structures can be imported from CAD files or programmed directly. This MPP system was tested for structuring in various photosensitive materials at large scale [31]. The ability to scale up and speed up the fabrication is ensured by changing the laser beam focusing objectives in the range from $100 \mathrm{x}$ NA $=1.4$ to $8 \mathrm{x}$ NA $=0.2$, reducing the resolution from $200 \mathrm{~nm}$ to $20 \mu \mathrm{m}$ [38].

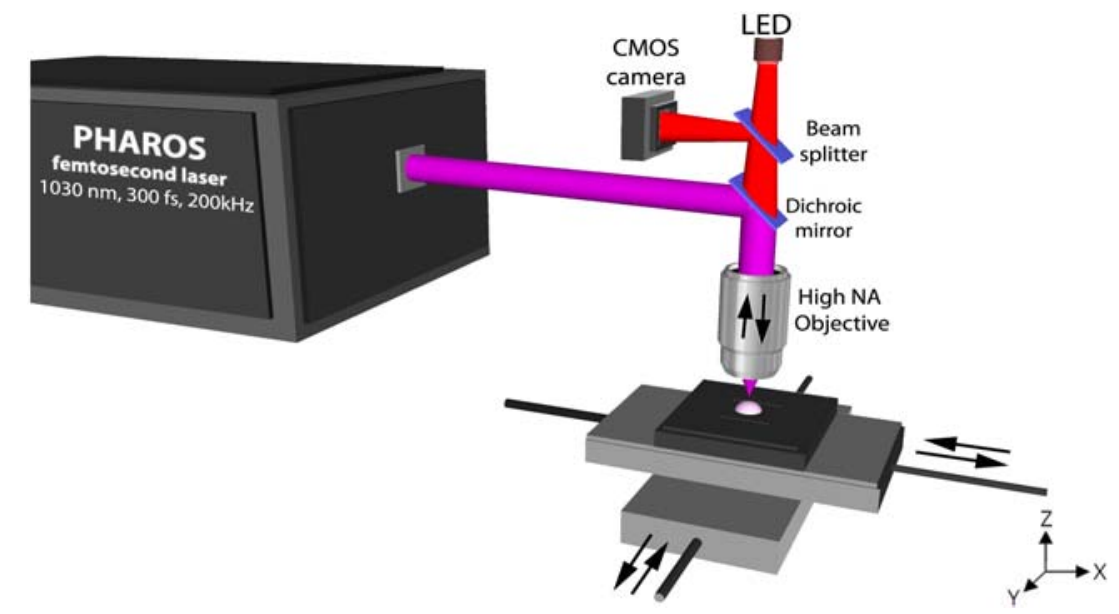

Fig. 1. The MPP fabrication setup. Femtosecond beam is reflected by dichroic mirror and coupled to high NA microscope objective. The sample is fixed on PC-controlled XYZ stages. The LED provides illumination for CMOS camera to optically monitor the fabrication process online.

According to Rayleigh's model, the focal spot size is limited by the diffraction, and is expressed as

$$
\begin{aligned}
& d=\frac{1.22 \lambda}{N A} ; \\
& l=\frac{2 \lambda n}{N A^{2}} ;
\end{aligned}
$$


where $d$ and $l$ are the lateral and longitudinal dimensions of the diffractionlimited spot;

$\lambda \quad$ is the exposure wavelength;

$N A \quad$ is the numerical aperture;

$n \quad$ is the refractive index of sample material [44].

It was observed that the resolution of the fabricated structures exceeds the diffraction limit when appropriate parameters are chosen (laser power $P$ or scanning speed $v$ corresponding to a shorter exposure at definite points) and can be defined using the following equations [45]:

$$
\begin{aligned}
& d=\frac{\lambda}{N A} \sqrt{\ln \frac{I_{0}^{2} t \beta \tau \nu}{I_{t h}}} ; \\
& l=\frac{2 z_{R}}{n} \sqrt{\exp \left(\frac{1}{2}\left(\frac{d N A}{\lambda}\right)^{2}\right)-1} ;
\end{aligned}
$$

here $I$ is the intensity in the vicinity of focus;

$t \quad$ is the exposure time;

$\beta \quad$ is the experimentally derived constant pertaining to the response of photosensitive material;

$\tau$ and $v$ are the laser pulse duration and repetition rate, respectively;

$I_{\text {th }} \quad$ is the intensity of polymerization threshold;

$z_{R} \quad$ is Rayleigh's range.

The dependence of resolution on the focusing optics is depicted in Fig. 2. The minimal photopolymerized volume is called voxel (volumetric pixel). The voxel shape strongly relies on the objective numerical aperture.

(a)

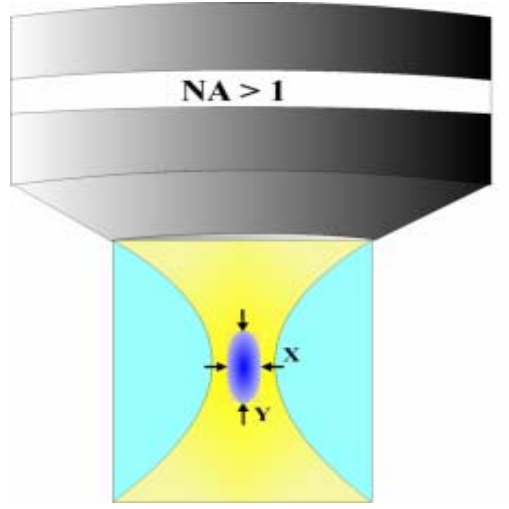

(b)

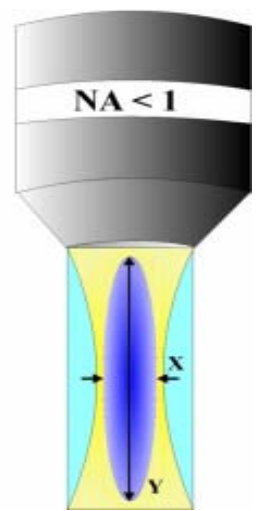

Fig. 2. Voxel shape dependence on the focusing optics. The formed voxel has length/width ratio $\sim 3$ for high NA $(>1)$ objective $(a)$ and up to 20 for low NA $(<1)$ objective $(b)$.

The resolution can be varied in a wide range by changing the microscope objectives (focusing optics) as well as tuning the laser power and exposure time (sample translation speed). Table 2 shows possible resolution intervals corresponding to the objective's numerical aperture. 


\begin{tabular}{|c|c|c|}
\hline $\mathrm{M}$ & $\mathrm{NA}$ & $\mathrm{X}, \mu \mathrm{m}$ \\
\hline $100 \mathrm{x}$ & 1.4 & $0.2-0.5$ \\
\hline $40 \mathrm{x}$ & 0.65 & $0.4-1$ \\
\hline $20 \mathrm{x}$ & 0.5 & $0.7-2$ \\
\hline $10 \mathrm{x}$ & 0.25 & $2.5-15$ \\
\hline
\end{tabular}

\section{RESULTS}

\subsection{Fabrication of 3D artificial scaffolds}

To fabricate 3D artificial scaffolds designed for the tissue engineering, AKRE and SZ2080 photosensitive materials (known for their good micro- and nanostructuring properties) were chosen. Additionally, a PEG-DA-258 photopolymer was used as the biodegradable material.

Fabrication procedure is shown in Fig. 3. The structure is obtained using the focused laser light inducing a localized monomer-to-polymer conversion. Afterwards, the unexposed material is washed out with developer revealing the $3 \mathrm{D}$ object on the substrate.
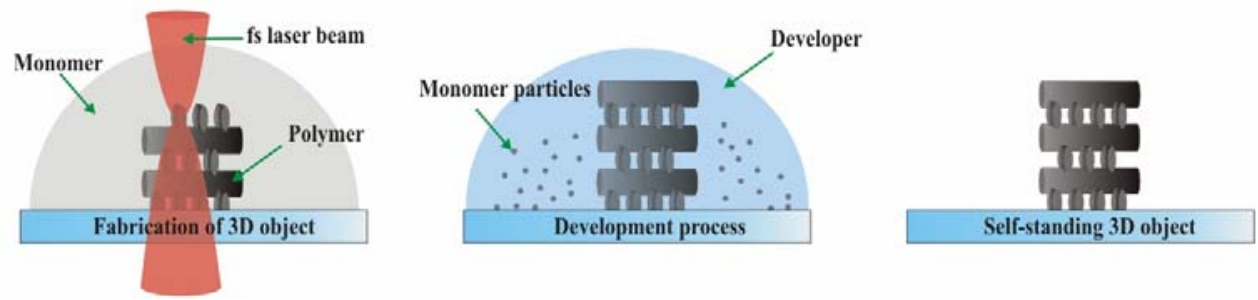

Fig. 3. MPP fabrication steps of point-by-point photostructuring and development.

An example of the rigid true 3D structure obtained is shown in Fig. 4. The scaffold could be directly produced from its CAD model (Fig. $4 a$ ). The real object (Fig. $4 b$ ) differs from its original model because of shrinkage during conversion from liquid to solid state, and the structure is deformed due to capillary forces during development. Such structures could be promising artificial scaffolds for cell proliferation in 3D, exhibiting high mechanical strength as they are made of spatial figures $-3 \mathrm{D}$ honey-comb structures with intentionally introduced gaps.

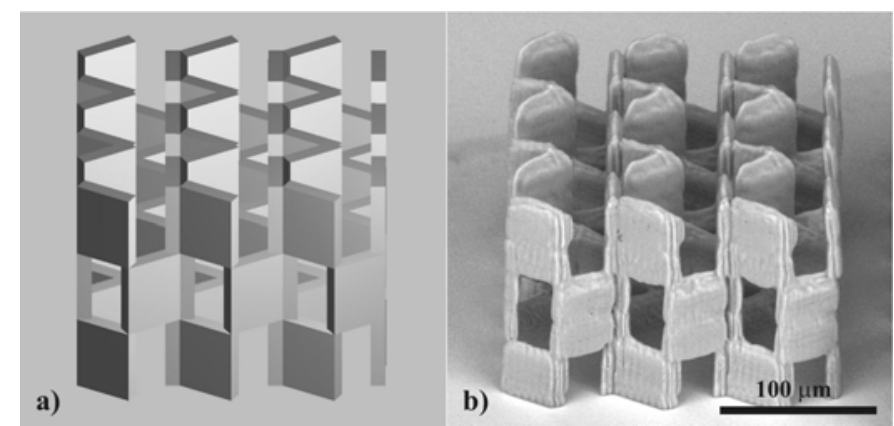

Fig. 4. a) CAD model of porous 3D honeycomb scaffold; $b$ ) microstructure fabricated of hybrid organic-inorganic biocompatible polymer SZ2080. 
The pore size of the scaffold has to be approximately twice as big as the size of a single cell; for mammals this would correspond to tens of micrometers [46]. Precise control of pore sizes, their homogeneity and interconnection is believed to be beneficial for cell proliferation [47]. Also, scaffold stiffness and biodegradability will depend on the inner architecture and the filling factor $\left(V_{\text {material }} / V_{\text {scaffold }}\right)$ [48].

\subsection{Growing stem cells on the polymeric scaffolds}

For the cell-based artificial tissue fabrication on the MPP engineered scaffolds the adult stem cells derived from rabbit muscle were used. Myogenic stem cells were isolated from skeletal muscle tissue and grown in Iscove's modified Dulbecco minimum essential medium (Sigma-Aldrich $\mathrm{GmbH}$ ) supplemented with $10 \%$ fetal calf serum (Sigma-Aldrich $\mathrm{GmbH}$ ) in multiple polystyrene tissue culture plates (Orange Scientific, Switzerland) [49, 50].

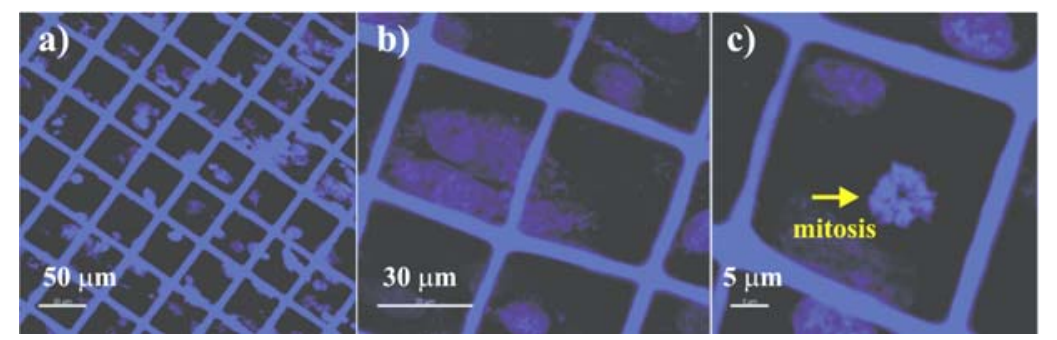

Fig.5. Rabbit adult stem cells extended on the SZ2080 scaffolds. Pore size is $\sim 50 \mu \mathrm{m}$. DAPI-stained cells' nuclei fluoresce in blue.

Next, the primary adult myogenic stem cell line was used for constructing a cell-based artificial tissue on the MPP engineered scaffolds. Prior to introducing cells into the well containing a scaffold, they were stained with $10 \mu \mathrm{g} / \mathrm{ml} \mathrm{di-}$ amidino-2-phenylindole (DAPI) - the classic blue fluorescent probe for viable cells that fluoresce brightly when bound to DNA. Therefore, DAPI-stained myogenic stem cells were cultured on the AKRE material or hybrid organic-inorganic SZ2080 and PEG-DA-258 MPP engineered scaffolds (Figs. 5-7). The cells were inoculated at a density of 60000 units per $\mathrm{ml}$. After $72 \mathrm{~h}$ cultivation, the proliferation of stem cells on the MPP scaffolds was assessed microscopically.

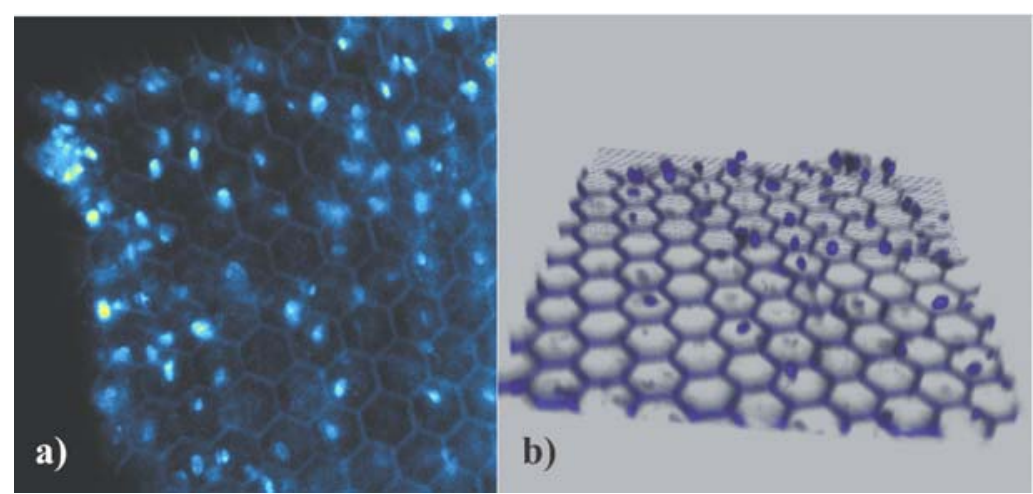

Fig. 6. Fluorescence $a$ ) and confocal $b$ ) microscope images showing the blue stained cells attached to AKRE (polymeric material structured as a honey-comb grid). 

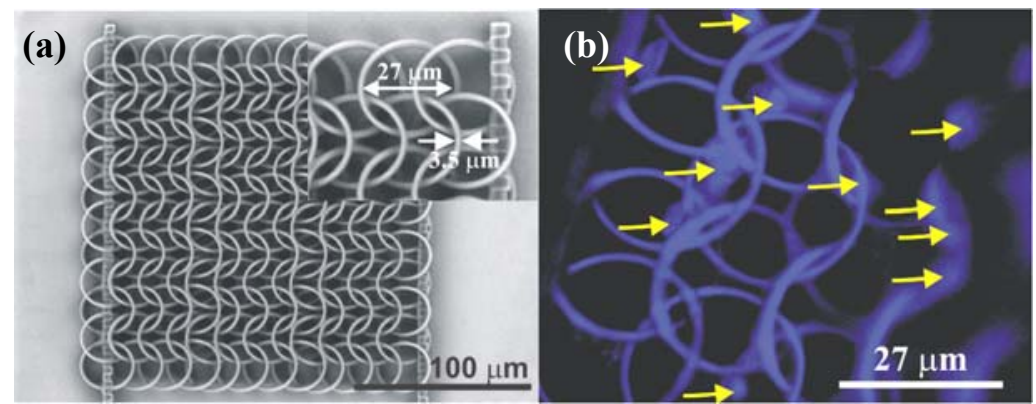

Fig. 7. The chain-mail structure made of intertwined rings as a flexible scaffold: SEM and fluorescence microscopy obtained images, $a$ ) and $b$ ), respectively. Pore size is $\sim 27 \mu \mathrm{m}$. The arrows point to fluorescing cells nuclei $(b)$.

\section{DISCUSSION}

For modern implants and cell-based artificial tissues it is important to engineer structures with characteristics that closely emulate nature. The advances in various fields of science enable and enforce the scientists to search for novel biocompatible materials with distinct properties and innovative design, which are necessary for engineering contemporary composite tissue with a purposeful orientation towards anatomic structures. The MPP technique opens a way to manufacture custom-shaped scaffolds with submicrometer resolution from variety biocompatible materials which can be photocured. This approach is attractive for its unmatched flexibility, relatively high throughput and easy-to-use automated system that enables direct "materialization" of CAD models in the object having spatial features of micro- or nanoscale. Our fabricated artificial 3D scaffolds are distinguished by complex architecture and can serve as templates for growing cells. The adult stem cells proliferation experiments have proved the photostructurable matrials and MPP-produced structures to be promising for tissue engineering applications. Besides, it should be noted that by patterning the surface roughness at nanoscale, the hydrophilic/hydrophobic properties of laser-processed polymers (as well as artificial scaffold structures produced from them) can be controllably tuned within a wide range $[51,52]$.

\section{CONCLUSIONS}

We have constructed a multi-photon polymerization system based on diodepumped solid state $\mathrm{Yb}: \mathrm{KGW}$ fs laser setup in combination with linear driven stages for routine high resolution and throughput $3 \mathrm{D}$ micro- and nanofabrication. The system was used for producing artificial 3D polymeric scaffolds mimicking native ones applied for stem cell growth. Polymeric scaffolds of biocompatible photopolymers up to $1 \mathrm{~cm}^{2}$ in lateral size and having sub-micrometer spatial feature resolution were successfully fabricated. Proliferation tests on myogenic stem cells taken from adult rabbits have shown artificial scaffolds to be applicable in biomedicine practice. However, further investigations into scaffolds' biocompatibility and bio-degradability in vivo as well as into mechanical properties of the structures have to be done before the regenerative medicine puts these scaffolds into practice. Of promise would be to use them for making artificial pericardium in the experimental model of laboratory animals in near future. 


\section{ACKNOWLEDGEMENTS}

This research was funded by Grant No. MIP-10344 ("Creation of Artificial Tissues for Regenerative Medicine") from the Research Council of Lithuania. Part of the work was supported by Grant No. 228334 ("OPTOBIO") in the framework of EC's Seventh Framework Programme LASERLAB-EUROPE. The authors gratefully acknowledge A. Gaidukevičiūtè and Dr. M. Farsari (Foundation of Research and Technology Hellas, bmm@iesl.forth.gr) for providing Zr-containing sol-gel hybrid photosensitive material SZ2080. Special thanks are expressed to Altechna Ltd. for providing assembled Aerotech stages.

\section{REFERENCES}

1. Farsari, M., \& Chichkov, B.N. (2009). Materials processing: two-photon fabrication. Nat. Photonics, 3, 450-452.

2. Ostendorf, A., \& Chichkov, B.N. (2006). Two-photon polymerization: a new approach to micromachining. Photon. Spectra, 40 (10), 72-80.

3. Naulleau, P.P., Anderson, C.N., Chiu, J., Denham, P., George, S., Goldberg, K.A., Goldstein, M., Hoef, B., Hudyma, R., Jones, G., Koh, C., La Fontaine, B., Ma, A., Montgomery, W., Niakoula, D., Park, J., Wallow, T., \& Wurm, S. (2009). 22-nm halfpitch extreme ultraviolet node development as the SEMATECH Berkeley microfield exposure tool. Microelectron. Eng., 86 (4-6), 448-455.

4. Sunne, G.R. (2008). Electron beam lithography for nanofabrication. PhD thesis, University of Barcelona (Barcelona), 17-21.

5. Schift, H. (2008). Nanoimprint lithography: an old story in modern times? (a review). J. Vac. Sci. Technol., B 26 (2), 458-480.

6. Rousset, S., \& Ortega, E. (2006). Self-organized nanostructures. J. Phys.: Condens. Matter, 18 (13).

7. Xia, Y., \& Whitesides, G.M. (1998). Soft lithography. Ann. Rev. Mater. Sci., 28 (1), 153-184.

8. Stampfl, J., Baudis, S., Heller, C., Liska, R., Neumeister, A., Kling, R., Ostendorf, A., \& Spitzbart, M. (2008). Photopolymers with tunable mechanical properties processed by laser-based high-resolution stereolithography. J. Micromech. Microeng., 18 (12), 125014.

9. Walther, M., Ortner, A., Meier, H., Löffelmann, U., Smith, P. J., \& Korvink, J. G. (2009). Terahertz metamaterials fabricated by inkjet printing. Appl. Phys. Lett., 95, (25), 251107.

10. Dengfeng, T., Yan, L., Fengjie, Q., Hong, Y., Qihuang, G., Xianzi, D., \& Xuanming, D. (2007). Reduction in feature size of two-photon polymerization using SCR500. Appl. Phys. Lett., 90 (7), 071106.

11. Maruo, S., Takaura, A., \& Saito, Y. (2009). Optically driven micropump with a twin spiral. Microrotor. Opt. Express, 17 (21), 18525-18532.

12. Wu, D., Chen, Q., Niu, L., Wang, J., Wang, J., Wang, R., Xia, H., \& Sun, H. (2009). Femtosecond laser rapid prototyping of nanoshells and suspending components towards microfluidic devices. Lab. Chip., (9), 2391-2394.

13. Sun, Q., Juodkazis, S., Murazawa, N., Mizeikis, V., \& Misawa, H. (2010). Freestanding and movable photonic microstructures fabricated by photopolymerization with femtosecond laser pulses. J. Micromech. Microeng., 20 (3), 035004.

14. Malinauskas, M., Gilbergs, H., Žukauskas, A., Purlys, V., Paipulas, D., \& Gadonas, R., (2010). A femtosecond laser induced two-photon photopolymerization technique for structuring microlenses. J. Opt., 12 (3), 035204. 
15. Ovsianikov, A., Schlie, S., Ngezahayo, A., Haverich, A., \& Chichkov, B. N. (2008). Two-photon polymerization technique for microfabrication of CAD-designed 3D scaffolds from commercially available photosensitive materials. J. Tissue. Eng. Regen. Med., 1 (6), 443-449.

16. Griffith, L.G., \& Naughton, G. (2002). Expanding opportunities in tissue engineering current challenges. Science, 295 (5557).

17. Malinauskas, M., Danilevičius, P., Baltriukienè, D., Rutkauskas, M., Žukauskas, A., Kairytė, Ž., Bičkauskaite, G., Purlys, V., Paipulas, D., Bukelskienė, V., \& Gadonas, R. (2010). 3D artificial polymeric scaffolds for stem cell growth fabricated by femtosecond laser. Lithuanian J. Phys., 50 (1), 75-82.

18. Hutmacher, D.W. (2000). Scaffolds in tissue engineering of bone and cartilage. Biomaterials, 21(24), 2529-2543.

19. Lutolf, M.P., \& Hubbell, J.A. (2005). Synthetic biomaterials as instructive extracellular microenvironments for morphogenesis in tissue engineering. Nat. Biotechnol., 23, 47 55.

20. Li, Y., Yang, S. (2001). Effects of three-dimensional scaffolds on cell organization and tissue development. Biotechnol. Bioprocess Eng., 6 (5), 311-325.

21. Braukel, J.H., Brendel, Z.E., Martinson, L.A., Crudele, J., Johnston, W.D., \& Johnson, R.C. (1995). Neovascularization of synthetic membranes directed by membrane microarchitecture. J. Biomed. Mater. Res., 29 (12) 1517-1524.

22. Nehrer, S., Breinan, H.A., Ramappa, A., Young, G., Shortkroff, S., Louie, L.K, Sledge, C.B., Yannas, I.V. \& Spector, M. (1997). Matrix collagen type and pore size influence behaviour of seeded canine chondrocytes. Biomaterials, 18 (11), 769-776.

23. Whang, K., Thomas, C.H., \& Healy, K.E. (1995). A novel method to fabricate bioabsorbable scaffolds. Polymer, 36, 837-842.

24. Wake, M.C., Patrick, C.W., \& Mikos, A.G. (1994). Pore morphology effects on the fibrovascular tissue growth in porous polymer substrates. Cell Transplantation, (3), 339-343.

25. Yannas, I., Lee, Z.E., Orgil, O.E., Krabut, E.M., \& Murphy, E. (1989). Synthesis and characterization of a model extracellular matrix that induces partial regeneration of adult mammalian skin. Proc. Natl. Acad. Sci. (USA), 86, 933-937.

26. Patrick, C.W., Chauvin, E.B., Hobley, J. \& Reece, G.P. (1999). Preaclipocyte seeded PLGA scaffolds for adipose tissue engineering. Tissue Eng., 5 (2), 139-151.

27. Boyan, B.D., Humnert, Z., Dean, D.D., \& Schwartz, Z. (I996). Role of material surfaces in regulating bone and cartilage cell response. Biomaterials, 17 (2), 137-146.

28. Ma, P.X., (2004). Scaffolds for tissue fabrication. Mater. Today, 7 (5), 38-40.

29. Tayalia, P., Mendonca, C. R., Baldacchini, T., Mooney, D.J., Mazur, E. (2008). 3D cell-migration studies using two-photon engineered polymer scaffolds. Adv. Mater., 20 (23), 4494-4498.

30. Claeyssens, F., Hasan, E.A., Gaidukevičiūtè, A., Achilleos, D.S., Ranella, A., Reinhardt, C., Ovsianikov, A., Shizhou, X., Fotakis, C., Vamvakaki, M., Chichkov, B.N., \& Farsari, M. (2009). Three-dimensional biodegradable structures fabricated by twophoton polymerization. Langmuir, 25 (5), 3219-3223.

31. Malinauskas, M., Purlys, V., Rutkauskas, M., \& Gadonas, R. (2009). Two-photon polymerization for fabrication of three-dimensional micro- and nanostructures over a large area. SPIE Proc., 7204, 72040C.

32. Gittard, S.D., Narayan, R.J., Lusk, J., Morel, P., Stockmans, F., Ramsey, M., Laverde, C., Phillips, J, Monteiro-Riviere N.A, Ovsianikov, A. \& Chichkov B.N. (2009). Rapid prototyping of scaphoid and lunate bones. Biotechnol. J., 4 (1), 129-134.

33. Stampfl, J., Baudis, S., Heller, C., Liska, R., Neumeister, A., Kling, R., Ostendorf, A., \& Spitzbart, M. (2008). Photopolymers with tunable mechanical properties processed 
by laser-based high-resolution stereolithography. J. Micromech. Microeng., 18 (12), 125014.

34. Cumming, D.R.S, Thoms, S., Beaumont, S.P., \& Weaver J.M.R. (1996). Fabrication of $3 \mathrm{~nm}$ wires using $100 \mathrm{keV}$ electron beamlithography and poly(methyl methacrylate) resist, Appl. Phys. Lett., 68 (3), 322-324.

35. Chen, W., \& Ahmed, H. (1993). Fabrication of 5-7 nm wide etched lines in silicon using $100 \mathrm{keV}$ electron-beam lithography and polymethylmethacrylate resist. Appl. Phys. Lett., 62 (13), 1499-1501.

36. Schizas, C., Melissinaki, V., Gaidukevičiūtė A., Reinhardt, C., Ohrt, C., Dedoussis, V., Chichkov, B.N., Fotakis, C., Farsari, M., \& Karalekas, D. (2009). On the design and fabrication by two-photon polymerization of a readily assembled micro-valve. Int. $J$. Adv. Manuf. Technol., 48 (5-8), 435-441.

37. Passinger, S., Ovsianikov, A., Kiyan, R., Reinhardt, C., Ostendorf, A., \& Chichkov, B.N. (2008). Two-photon polymerization for industrial applications. Proc LPM 2008.

38. Malinauskas, M., Purlys, V., Rutkauskas, M., Gaidukevičūtè, A., \& Gadonas R. (2010). Femtosecond visible light induced two-photon photopolymerization for 3D micro/nanostructuring in photoresists and photopolymers. Lithuanian J. Phys., 50 (2), 201-207.

39. Weiß, T., Hildebrand, G., Schade, R., \& Liefeith, K. (2009). Two-photon polymerization for microfabrication of three-dimensional scaffolds for tissue engineering application. Eng. Life Sci., 9 (5), 384-390.

40. Ovsianikov, A., Viertl, J., Chichkov, B.N, Oubaha, M., MacCraith, B., Sakellari, I., Giakoumaki, A., Gray, D., Vamvakaki, M., Farsari, M., \& Fotakis, C. (2008). Ultralow shrinkage hybrid photosensitive material for two-photon polymerization microfabrication. ACS Nano, 2 (11), 2257-2262.

41. Ovsianikov, A., Gaidukevičiūtè, A., Chichkov, B.N, Oubaha, M. MacCraith, B.D, Sakellari, I., Giakoumaki, A., Gray, D., Vamvakaki, M., Farsari, M., \& Fotakis C. (2008). Two-photon polymerization of hybrid sol-gel materials for photonics applications. Laser Chem., 493059.

42. Ovsianikov, A., Ostendorf, A., \& Chichkov, B.N. (2007). Three-dimensional photofabrication with femtosecond lasers for applications in photonics and biomedicine. Appl. Surf. Sci., 253 (15), 6599-6602.

43. Ovsianikov, A., Malinauskas, M., Schlie, S., Chichkov, B., Gittard, S., Narayan, R., Löbler, M., Sternberg, K., Schmitz, K.-P., Haverich, A. (2011). Three-dimensional laser micro- and nano-structuring of acrylated poly(ethylene glycol) materials and evaluation of their cytoxicity for tissue engineering applications. Acta Biomater., 7, 967-974.

44. Inoue, S., \& Oldenbourg, R. (1995). Handbook of optics: devices, measurements and properties, Vol. 2, ed. M. Bass (McGraw. Hill), 566-568.

45. Liu, Y, Pyrak-Nolte, L., \& Nolte, D. (2008). General 3D microporous structures fabricated with two-photon lasermachining. SPIE Proc., 6886, 68860Y.

46. Chachques, J.C., Trainini, J.C., Lago, N., Cortes-Morichetti, M., Schussler, O., \& Carpentier, A. (2008). Myocardial assistance by grafting a new bioartificial upgraded myocardium magnum trial: Clinical feasibility study. Ann. Thorac. Surg., 85, 901-908.

47. Weng, J., \& Wang, M. (2001). Producing chitin scaffolds with controlled pore size and interconnectivity for tissue engineering. J. Mater. Sci. Lett., 20, 1401-1403.

48. Hollister, S.J, Maddox, R.D., \& Taboas, J.M. (2002). Optimal design and fabrication of scaffolds to mimic tissue properties and satisfy biological constraints. Biomater., 23 (20), 4095-4103.

49. Bukelskienè, V., Baltriukienè, D., Bironaitè, D., Imbrasaitė, A., Širmenis, R., Balčiūnas, M., Žurauskas, E., \& Kalvelytè, A. (2005). Muscle derived primary stem cell lines for heart repair. Sem. Cargiol., 11 (3), 99-105. 
50. Širmenis, R., Bukelskienė, V., Domkus, V., \& Sirvydis, V. (1999). Cellular cardiomyoplasty: isolation and cultivation of skeletal musclesatellite cells. Acta Med. Lituanica, (6), 178-181.

51. Paital, S.R., Cao, Z., He, W., \& Dahotre, N.B. (2010). Wetting effects on in vitro bioactivity and in vitro biocompatibility of laser micro-textured $\mathrm{Ca}-\mathrm{P}$ coating. Biofabrication, (2), 025001.

52. Zhang, D., Chen, F., Fang, G., Yang, Q., Xie, D., Qiao, G., Li, W., Si, J., \& Hou, X. (2010). Wetting characteristics on hierarchical structures patterned by a femtosecond laser. J. Micromech. Microeng., (20), 075029.

\section{AR LĀZERU IZGATAVOTIE MIKRO/NANO 3D POLIMĒRI PIELIETOŠANAI AUDU INŽENIERIJĀ}

P. Danilevičius, A. Žukauskas, G. Bičkauskaitè, V. Purlys, M. Rutkauskas, T. Gertus, D. Paipulas, J. Matukaite, D. Baltriukienè, M. Malinauskas

Kopsavilkums

Šajā darbā mēs izveidojām un pielietojām multi-fotonu polimerizācijas sistēmu, kuras pamatā ir impulsa apstarošanas gaismas avots (diode-pumped solid state femtosecond laser $\mathrm{Yb}: \mathrm{KGW}, 300 \mathrm{fs}, 1030 \mathrm{~nm}, 100-200 \mathrm{kHz}$ ) kombinācijā ar lielu darba zonu un augstas precizitātes lineāro motoru vadāmiem posmiem $\left(100 \times 100 \times 50 \mathrm{~mm}^{3}\right)$. Šì sistēma ir paredzēta augstas izšķirtspējas un efektivitātes 3D mikro-nanofabrikācijai un ļauj ražot polimēru paliktņus $1 \overline{1} \mathrm{dz} 1 \mathrm{~cm}^{2}$ platībai ar sub-mikrometru izšksirtspēju. To var izmantot, lai ražotu 3D mākslīgo polimēru veidnes, kas pielietojamas šūnu izaugsmei audu inženierijā. Dažādu akrilātu, hibrīdu organisko-neorganisko un bio-sadalāmo polimēru materiālu bio-savietojamība tiek vērtēta eksperimentāli in vitro. Veiksmīgi tika izgatavotas visdažādāko izmēru un formu polimēru veidnes no bio-saderīgiem fotopolimēriem ar sarežǵìtu 3D ǵeometriju. Pieaugušo trušu miogeno cilmes šūnu proliferācijas testi parāda, ka mākslīgās veidnes ir piemērojamas biomedicīnas praksē.

11.01.2011. 